\title{
Penanganan terhadap kecelakaan lalu lintas di Kota Probolinggo
}

\section{Handling of traffic accidents in Probolinggo city}

\author{
Kadek Aditya Yasa Putra \\ Program Studi Kajian Ilmu Kepolisian, Sekolah Pascasarjana, Universitas Airlangga \\ Surabaya, 60286, Jawa Timur, Indonesia \\ E-mail: kadek.aditya.yasa-2016@pasca.unair.ac.id
}

\begin{abstract}
Abstrak
Penelitian ini bertujuan untuk mengetahui dan menganalisis faktor-faktor penyebab kecelakaan lalu lintas dan menganalisis penanganan investigasi terhadap kecelakaan lalu lintas di Kota Probolinggo. Metode penelitian yang digunakan adalah deskriptif kualitatif, dengan teknik wawancara, observasi dan dokumentasi. Studi ini menunjukkan bahwa karakteristik kecelakaan lalu lintas di Kota Probolinggo, yaitu kecenderungan kecelakaan lalu lintas dimulai dengan sikap pelanggar. Karakteristik faktor manusia pada tahun 2018 adalah sebagai berikut: usia pelaku didominasi oleh usia 26-30 tahun dan 31-40, di mana pada usia itu, dapat dikategorikan ke dalam usia produktif adalah pekerja. Jenis kelamin pelaku didominasi oleh laki-laki. Sementara itu, profesi didominasi oleh sektor swasta. Faktor-faktor yang menyebabkan kecelakaan lalu lintas adalah faktor kelalaian pengemudi dan faktor kendaraan, di mana kelalaian pengemudi terkait dengan lalu lintas yang tidak teratur seperti kecepatan dan rambu lalu lintas. Sedangkan faktor kendaraan yang terkait dengan kendaraan jarang dirawat oleh pengemudi, sehingga menyebabkan kerusakan pada kendaraan. Penanganan penyelidikan kecelakaan lalu lintas di Kota Probolinggo adalah dengan memetakan area blackspot, membantu korban kecelakaan yang melakukan investigasi, investigasi dan penangkapan/penahanan tersangka.
\end{abstract}

Kata kunci: penanganan; kecelakaan; investigasi; polisi; lalu lintas

\begin{abstract}
This study aims to determine and analyze the factors that cause traffic accidents and analyze the handling of investigations of traffic accidents in the City of Probolinggo. The research method used is descriptive qualitative, with interview, observation and documentation techniques. This study shows that the characteristics of traffic accidents in the City of Probolinggo, namely the tendency of traffic accidents begins with the attitude of offenders. Characteristics of human factors in 2018 are as follows: the age of the offender is dominated by the age of 26-30 years and 31-40, where at that age, it can be categorized into the productive age as workers. The sexes of the perpetrators are dominated by men. Meanwhile, the profession is dominated by the private sector. Factors that cause traffic accidents are driver negligence and vehicle factors, where the negligence of the driver is related to irregular traffic such as speed and traffic signs. While vehicle factors related to vehicles are rarely treated by the driver, causing damage to the vehicle. The handling of traffic accident investigations in the City of Probolinggo is to map blackspot areas, assist accident victims who investigate, investigate and arrest / detain suspects.
\end{abstract}

Keywords: handling; accident; investigation; Police; traffic

\section{Pendahuluan}

Salah satu persoalan yang selalu dihadapi di kota-kota besar adalah lalu lintas. Persoalan lalu lintas yang dihadapi oleh kota-kota besar antara lain, yaitu kemacetan, kecelakaan lalu lintas dan pelanggaran lalu lintas (Tamin 1992; Firman 1998; Tamin 2005; Steinberg 2007). Keadaan ini merupakan salah satu perwujudan dari perkembangan teknologi transportasi yang modern. Perkembangan lalu lintas itu sendiri dapat memberi pengaruh, baik yang bersifat negatif maupun yang bersifat positif bagi kehidupan masyarakat (Kurniawan 2016). Hal ini nampak telah membawa pengaruh terhadap keamanan lalu lintas yang semakin sering terjadi, pelanggaran lalu lintas yang menimbulkan kecelakaan lalu lintas dan kemacetan lalu lintas. Kecelakaan lalu lintas disebabkan oleh banyak faktor tidak sekedar oleh pengemudi kendaraan yang buruk, pejalan kaki yang kurang hatihati, kerusakan kendaraan, rancangan kendaraan, cacat pengemudi, rancangan jalan, dan kurang mematuhinya rambu-rambu lalu lintas (Chakrabartty \& Gupta 2014). 
Kecelakaan lalu lintas di jalan raya menyebabkan kematian sekitar 1,25 juta manusia setiap tahun di seluruh dunia. Demikian laporan yang dirilis Organisasi Kesehatan Dunia (World Health Oganitation/WHO). Kasus kecelakaan lalu lintas jalan yang mematikan yang terjadi di Indonesia sendiri dan dilaporkan pada tahun 2013 mencapai 26.416, namun estimasi WHO mencapai 38.279. Korban kecelakaan terbesar pada pengendara sepeda motor dan kendaraan roda tiga, yaitu 36 persen, pengemudi dan penumpang bus mencapai 35 persen, dan pejalan kaki mencapai 21 persen. Sedangkan jumlah kendaraan di Indonesia mencapai 104 juta lebih untuk semua jenis. Ironisnya tidak semua orang yang terlibat dalam kecelakaan tersebut murni bersalah tetapi tetap saja dijadikan sebagai tersangka (Nainggolan 2014), Tidak terkecuali di Kota Probolinggo. Jumlah kejadian kecelakaan yang terjadi di Kota Probolinggo mencapai 1.003 kasus selama tiga tahun. Adapun korban meninggal dunia berjumlah 241 orang, korban luka berat berjumlah 9 (Sembilan) orang dan korban luka ringan berjumlah 1.453 orang. Hal ini mengindikasikan bahwa kecelakaan yang terjadi di Probolinggo relatif tinggi. Untuk lebih jelas, maka akan digambarkan satu kasus kecelakaan lalu lintas yang terjadi di Kota Probolingg. Kasus yang terjadi antara Bus dan Truk yang mana menewaskan 10 orang. Akibat jalan yang meningkung tajam, sementara Bus berkendara dengan kecepatan tinggi dan sopir bus tidak menguasi medan jalan, sehingga terjadi kecelakaan lalau lintas (Rofiq 2017).

Di sisi lain, dalam melaksanakan tugas dan sebagai alat negara, Polri memberikan perlindungan, pengayoman dan pelayanan kepada masyarakat, harus dilakukan bersama dan menyatu dengan masyarakat. Salah satu bentuk dari pelaksanaan tugas kepolisian adalah melakukan pelayanan kepada masyarakat di bidang lalu lintas. Tugas polisi sebagai penyidik dalam sistem peradilan pidana menempatkannya dalam jajaran paling depan, sehingga polisi dituntut untuk bisa menyeleksi atau memilah-milah perkara mana yang pantas untuk diajukan ke pengadilan atau tidak berdasarkan peraturan perundang-undangan. Tanpa adanya penyeleksian oleh polisi pada saat penyidikan maka akan terjadi penumpukan perkara yang nantinya tidak efektif dan efisien bagi semua pihak. Dalam hal ini pengambilan keputusan oleh polisi menjadi hal yang penting adanya (Djatmika \& Zakaria 2013).

Kepolisian yang bertugas dalam menetapkan status tersangka harus paham mengenai perumusan penyidikan. Karena kekurangpahaman dalam memaknai suatu rumusan penyidikan tentu akan berpengaruh dalam menunjukkan ada tidaknya hubungan rangkaian perbuatan dengan akibatnya, dan barang bukti yang diajukan di persidangan serta yang tercantum dalam BAP (Berita Acara Pidana) berbeda dengan yang terungkap dalam persidangan tersebut benar adanya, ini jelas sangat memprihatinkan dalam proses penegakan hukum.

Kepolisian merupakan suatu lembaga negara yang berperan dalam memelihara keamanan dan ketertiban masyarakat, menegakkan hukum, serta memberikan perlindungan, pengayoman, dan pelayanan kepada masyarakat dalam rangka terpeliharanya keamanan dalam negeri. (Sentanu et al. 2014). Tugas pokok Kepolisian Negara Republik Indonesia adalah: (a) memelihara keamanan dan ketertiban masyarakat; (b) menegakkan hukum; dan (c) memberikan perlindungan, pengayoman, dan pelayanan kepada masyarakat (Pasal 13 Undang-Undang Nomor 2 Tahun 2002 tentang Kepolisian Negara Republik Indonesia). Dalam melaksanakan tugas pokok sebagaimana dimaksud dalam Pasal 13 diatas, Kepolisian Negara Republik Indonesia bertugas salah satunya melakukan penyelidikan dan penyidikan terhadap semua tindak pidana sesuai dengan hukum acara pidana dan peraturan perundang-undangan lainnya (Sentanu et al. 2014).

Sementara itu, dalam rangka menyelenggarakan tugas sebagaimana dimaksud dalam Pasal 13 dan 14 Undang-Undang Nomor 2 Tahun 2002 tentang Kepolisian Negara Republik Indonesia di bidang proses pidana Kepolisian Negara Republik Indonesia berwenang untuk melakukan penangkapan, penahanan, penggeledahan dan penyitaan, melarang setiap orang meninggalkan atau memasuki tempat kejadian perkara untuk kepentingan penyidikan, membawa dan menghadapkan orang kepada penyidik dalam rangka penyidikan, menyuruh berhenti orang yang dicurigai dan menanyakan serta memeriksa tanda pengenal diri, melakukan pemeriksaan dan penyitaan surat, memanggil orang untuk didengar dan diperiksa sebagai tersangka atau saksi, mendatangkan orang ahli yang diperlukan dalam hubungannya dengan pemeriksaan perkara; mengadakan penghentian penyidikan, menyerahkan berkas perkara kepada penuntut umum, mengajukan permintaan secara langsung kepada pejabat 
imigrasi yang berwenang di tempat pemeriksaan imigrasi dalam keadaan mendesak atau mendadak untuk mencegah atau menangkal orang yang disangka melakukan tindak pidana, memberi petunjuk dan bantuan penyidikan kepada penyidik pegawai negeri sipil serta menerima hasil penyidikan penyidik pegawai negeri sipil untuk diserahkan kepada penuntut umum, dan mengadakan tindakan lain menurut hukum yang bertanggung jawab.

Penyidikan merupakan tahapan penyelesaian perkara pidana setelah penyelidikan yang merupakan tahapan permulaan mencari ada atau tidaknya tindak pidana dalam suatu peristiwa. Ketika diketahui ada tindak pidana terjadi, maka saat itulah penyidikan dapat dilakukan berdasarkan hasil penyelidikan. Pada tindakan penyelidikan, penekanannya diletakkan pada tindakan "mencari dan menemukan" suatu "peristiwa" yang dianggap atau diduga sebagai tindakan pidana. Sedangkan pada penyidikan titik berat penekanannya diletakkan pada tindakan "mencari serta mengumpulkan bukti". Penyidikan bertujuan membuat terang tindak pidana yang ditemukan dan juga menentukan pelakunya. Pengertian penyidikan tercantum dalam Pasal 1 butir 2 KUHAP yakni dalam Bab I mengenai Penjelasan Umum, yaitu: "Penyidikan adalah serangkaian tindakan penyidik dalam hal dan menurut cara yang diatur dalam undang-undang ini untuk mencari serta mengumpulkan bukti yang dengan bukti itu membuat terang tentang pidana yang terjadi dan guna menemukan tersangkanya".

Berdasarkan rumusan Pasal 1 butir 2 KUHAP, unsur-unsur yang terkandung dalam pengertian penyidikan adalah: Pengertian penyidikan tercantum dalam Pasal 1 butir 2 KUHAP yakni dalam Bab I mengenai Penjelasan Umum, yaitu: "Penyidikan adalah serangkaian tindakan penyidik dalam hal dan menurut cara yang diatur dalam undang-undang ini untuk mencari serta mengumpulkan bukti yang dengan bukti itu membuat terang tentang pidana yang terjadi dan guna menemukan tersangkanya".

Berdasarkan rumusan Pasal 1 butir 2 KUHAP, unsur-unsur yang terkandung dalam pengertian penyidikan adalah: pertama, penyidikan merupakan serangkaian tindakan yang mengandung tindakantindakan yang antara satu dengan yang lain saling berhubungan. Kedua, penyidikan dilakukan oleh pejabat publik yang disebut penyidik. Ketiga, penyidikan dilakukan dengan berdasarkan peraturan perundang-undangan. Keempat, tujuan penyidikan ialah mencari dan mengumpulkan bukti, yang dengan bukti itu membuat terang tindak pidana yang terjadi, dan menemukan tersangkanya. Berdasarkan keempat unsur tersebut dapat disimpulkan bahwa sebelum dilakukan penyidikan, telah diketahui adanya tindak pidana tetapi tindak pidana itu belum terang dan belum diketahui siapa yang melakukannya. Adanya tindak pidana yang belum terang itu diketahui dari penyelidikannya.

Menurut F.D. Hobbs Kartika, mengungkapkan kecelakaan lalu lintas merupakan kejadian yang sulit diprediksi kapan dan dimana terjadinya. Kecelakaan tidak hanya trauma, cedera, ataupun kecacatan tetapi juga kematian. Kasus kecelakaan sulit diminimalisasi dan cenderung meningkat seiring pertambahan panjang jalan dan banyaknya pergerakan dari kendaraan Kurniawan Pasal 1 butir 24 Undang-Undang No. 22 tahun 2009 tentang Lalu-Lintas dan Angkutan Jalan menjelaskan bahwa yang dimaksud Kecelakaan Lalu Lintas adalah suatu peristiwa di Jalan yang tidak diduga dan tidak disengaja melibatkan. Kendaraan dengan atau tanpa Pengguna Jalan lain yang mengakibatkankorban manusia dan/atau kerugian harta benda.

Undang-undang Nomor 22 Tahun 2009 tentang Lalu Lintas dan Angkutan Jalan pasal 1 poin 24 menjelaskan definisi kecelakaan lalu lintas sebagai suatu peristiwa di jalan yang tidak diduga dan tidak disengaja melibatkan kendaraan dengan atau tanpa pengguna jalan lain yang mengakibatkan korban manusia dan/atau kerugian harta benda. Pasal 229 mengatur tentang penggolongan kecelakaan lalu lintas, yaitu: Kecelakaan Lalu Lintas ringan merupakan kecelakaan yang mengakibatkan kerusakan kendaraan dan/atau barang. Kecelakaan Lalu Lintas sedang merupakan kecelakaan yang mengakibatkan luka ringan dan kerusakan kendaraan dan/atau barang. Kecelakaan Lalu Lintas berat merupakan kecelakaan yang mengakibatkan korban meninggal dunia atau luka berat.

Direktorat Keselamatan Transportasi Darat menjelaskan bahwa yang dimaksud dengan kecelakaan yang serius adalah sebuah kecelakaan (satu kali kecelakaan) tetapi menelan korban meninggal dunia lebih besar dari delapan orang. Secara prinsip setiap kecelakaan lalu lintas jalan yang menimbulkan 
korban jiwa manusia harus dilakukan investigasi dan penelitian untuk mengetahui kemungkinan penyebab kecelakaan yang dapat dijadikan rekomendasi guna mencegah terjadinya kecelakaan serupa terulang kembali (Al Qurni 2013). Saat ini, kriteria kecelakaan yang diinvestigasi dan diteliti adalah kecelakaan lalu lintas jalan yang bersifat luar biasa, yaitu: kecelakaan lalu lintas jalan yang menimbulkan korban manusia yang mati delapan orang atau lebih, kecelakaan lalu lintas jalan yang menyebabkan prasarana rusak berat, kecelakaan lalu lintas jalan yang mengundang perhatian publik secara luas karena melibatkan tokoh ternama/penting atau figur publik, kecelakaan lalu lintas jalan yang menimbulkan polemik/kontroversi, kecelakaan yang berulang-ulang pada merk dan tipe kendaraan yang sama, kecelakaan yang sama pada satu titik lokasi lebih dari tiga kali dalam setahun, dan kecelakaan lalu lintas jalan yang mengakibatkan kerusakan/pencemaran lingkungan akibat bahan/limbah berbahaya beracun (B3).

\section{Metode Penelitian}

Penelitian ini menggunakan pendekatan metode kualitatif, dengan menggunakan metode studi kasus (case study), dimana dalam kajiannya mencoba mendalami suatu kasus tertentu secara lebih mendalam dengan melibatkan pengumpulan beraneka sumber informasi. Penelitian ini mengambil lokasi di wilayah hukum Polres Probolinggo, karena di wilayah hukum ini ditemukan kasus-kasus terkait kecelakaan lalu lintas yang beruntun dimana juga kian meresahkan masyarakat Kota Probolinggo. Kegiatan penelitian ini akan dimulai sejak disahkannya proposal penelitian serta surat ijin penelitian, yaitu bulan Mei sampai dengan Juni 2018. Adapun teknik pengumpulan data yang digunakan dalam penelitian ini yakni wawancara dan observasi. Adapun informan dalam penelitian ini adalah kepolisian (Kapolres Probolinggo Kota, Kasat Lantas Polres Probolinggo Kota, Kanit Dikyasa, Anggota Dikyasa) dan masyarakat pengguna jalan di sekitar wilayah hukum Polres Kota Probolinggo.

\section{Hasil dan Pembahasan}

\section{Karakteristik kecelakaan lalu lintas di Kota Probolinggo}

Berdasarkan studi dokumen yang dilakukan peneliti pada Satlantas Polres Probolinggo Kota, diketahui kecelakaan lalu lintas di wilayah hukum Probolinggo Kota dapat dibagi ke dalam beberapa kategori yaitu usia pelaku, jenis kelamin, profesi, jenis kecelakaan roda dua, dan jenis kecelakaan roda empat dari kurun waktu tahun 2012 sampai dengan Oktober 2017.

Tabel 1.

Data Kecelakaan Lalu Lintas Berdasarkan Usia Pelaku Laka Lantas Periode Tahun 2013 sampai dengan Oktober 2018

\begin{tabular}{llllllll}
\hline Tahun & Jumlah & \multicolumn{7}{c}{ Usia } \\
\cline { 3 - 8 } & Laka & $5-15$ & $16-25$ & $26-30$ & $31-40$ & $41-50$ & $51-60$ \\
\hline 2013 & 829 & 43 & 135 & 258 & 135 & 119 & 139 \\
\hline 2014 & 738 & 50 & 70 & 241 & 120 & 98 & 109 \\
\hline 2015 & 561 & 93 & 166 & 46 & 201 & 35 & 20 \\
\hline 2016 & 788 & 53 & 85 & 203 & 154 & 133 & 129 \\
\hline 2017 & 868 & 61 & 76 & 270 & 165 & 120 & 156 \\
\hline 2018 & 769 & 63 & 65 & 205 & 139 & 127 & 162 \\
\hline JUM & 4553 & 363 & 597 & 1003 & 905 & 632 & 724 \\
\hline
\end{tabular}

Sumber: Urmin Satlantas Polres Probolinggo Kota

Dari tabel 1 diketahui bahwa pelaku kecelakaan lalu lintas di wilayah hukum Polres Probolinggo Kota yang paling dominan adalah penduduk berusia antara 26-30 tahun, kemudian urutan kedua terbanyak adalah penduduk berusia 31-40 tahun. Terbukti pada penyebab kecelakaan untuk kelompok usia 26-30 tahun dan 31-40 tahun angka kasus dari tahun ke tahun terbilang sama, artinya tidak ada penurunan secara signifikan. Pada usia tersebut, dapat dikategorikan ke dalam usia dewasa, dimana usia produktif 
sebagai pekerja. Kemudian juga kelompok usia 31-40 tahun, yang dikategorikan sebagai usia produktif dapat dibilang ada kaitanya dengan sikap acuh terhadap peraturan lalu lintas. Kurangnya kesadaran berlalu lintas menjadikan kecelakaan lalu lintas pada kelompok-kelompok usia tersebut mengalami peningkatan. Faktor kecelakaan yang paling banyak menyebabkan kecelakaan di Kota Probolinggo adalah lengah, tidak tertib, dan lelah. Hal ini dimungkinkan karena mayoritas pelaku laka lantas adalah karyawan swasta atau usia produktif.

\section{Faktor penyebab kecelakaan lalu lintas di Kota Probolinggo}

Menurut Warpani, penyebab kecelakaan lalu lintas dapat dikelompokkan dalam empat unsur, yakni manusia, kendaraan, jalan, dan lingkungan (Warpani 2002). Secara umum ada tiga faktor utama penyebab kecelakaan; faktor pengemudi (road user), faktor kendaraan (vehicle), dan faktor lingkungan jalan (road environment). Kecelakaan yang terjadi pada umumnya tidak hanya disebabkan oleh satu faktor saja, melainkan hasil interaksi antar faktor lain. Hal-hal yang tercakup dalam faktorfaktor tersebut antar lain: faktor pengemudi, yaitu kondisi fisik (mabuk, lelah, sakit, dan sebagainya), kemampuan mengemudi, penyebrang atau pejalan kaki yang lengah, dan lain-lain. Faktor kendaraan yaitu, kondisi mesin, rem, lampu, ban, muatan, dan lain-lain. Faktor lingkungan jalan yaitu, desain jalan (median, gradien, alinyemen, jenis permukaan, dan sebagainya), kontrol lalu lintas (marka, rambu, lampu lalu lintas), dll. Faktor cuaca yaitu, hujan, kabut, asap, salju, dan lain-lain. Pada dasarnya faktor-faktor tersebut berkaitan atau saling menunjang bagi terjadinya kecelakaan. Namun, dengan diketahuinya faktor penyebab kecelakaan yang utama dapat ditentukan langkah-langkah penanggulangan untuk menurunkan jumlah kecelakaan.

Faktor yang paling sering menyebabkan kecelakaan dari keempat faktor di atas adalah faktor manusia, hal ini dikarenakan keceroboh, kesalahan pengemudi kendaraan sering dapat disimpulkan tidak mempergunakan peraturan lalu lintas (Shinar 1998; Boyce \& Geller 1999; Bjorklund \& Aberg 2005). Kecelakaan yang terjadi di Kota Probolinggo masih banyak diakibatkan karena kecepatan melaju pengendara yang tidak sesuai dengan keadaan keramaian jalan, sehingga menyebabkan kecelakaan tunggal. Pada umumnya, banyak pelanggaran yang dilakukan oleh manusia, misalnya tidak memberi tanda akan membelok, atau mengendarai mobil tidak di jalur kiri, atau pada suatu persimpangan tidak memberikan prioritas pada kendaraan lain yang datang dari sebelah kiri, atau menjalankan mobil terlalu cepat melampaui batas kecepatan yang ditentukan dalam rambu-rambu lalu lintas dan kurangnya berkonsentrasi saat mengemudikan kendaraannya (Parker et al. 1995; Mesken et al. 2002). Seperti yang telah diatur dalam Undang-undang No. 22 tahun 2009 tentang Lalu Lintas dan Angkutan Jalan pasal 106 ayat 1 yang berbunyi: "Setiap orang yang mengemudikan kendaraan bermotor di jalan wajib mengemudikan kendaraannya dengan wajar dan penuh kosentrasi".

Tingginya tingkat angka pertambahan kendaraan bermotor apabila ditinjau dari sektor keamanan dan keselamatan transportasi lalu lintas jalan raya menimbulkan dampak permasalahan yang cukup serius, apalagi bila dibandingan dengan pertambahan panjang dan lebar ruas jalan yang sangat sedikit mengakibatkan semakin rumit dampak permasalahan yang ditimbulkan (Ambarwati 2012). Kendaraan dapat menjadi faktor penyebab terjadinya kecelakaan lalu lintas bila tidak dikemudikan sebagaimana mestinya, sebagai akibat dari kondisi teknisnya yang tidak layak jalan atau penggunaan kendaraan yang tidak sesuai dengan aturan (Sivak 2002). Kecelakaan lalu lintas yang terjadi di Kota Probolinggo juga diakibatkan oleh kendaraan pengendara yang tidak dipelihara dengaan baik, sehingga menimbukan kerusakaan dan mengakibatkan kecelakaan tunggal.

Adapun sebab-sebab terjadinya kecelakaan lalu lintas yang diakibatkan oleh faktor kendaraan adalah sebagai berikut: pertama, perlengkapan kendaraan meliputi alat-alat rem tidak baik kerjanya, misal rem blong, alat-alat kemudi tidak baik kerjanya, ban atau roda kondisi kurang baik atau ban pecah, as muka atau belakang patah. Kedua, penerangan kendaraan meliputi tidak memenuhi aturan penerangan, menggunakan lampu yang menyilaukan pengemudi kendaraan lain. Ketiga, penggunaan kendaraan yang tidak sesuai dengan ketentuan, misalnya kendaraan diberi muatan melebihi kapasitasnya atau overloaded. Sehingga, dari hasil analisa tersebut maka harus ada kontrol dari aparat terkait uji kelayakan kendaraan guna meminimalisir angka kecelakaan (Girotto 2016). 


\section{Penanganan terhadap kecelakaan lalu lintas di Kota Probolinggo}

\section{Pelaksanaan mapping blackspot area}

Diketahuinya karakteristik kecelakaan maka dapat dilakukan perhitungan secara ilmiah yang pada akhirnya akan bermanfaat dalam menentukan titik black spot (rawan kecelakaan) setiap kilometer sebuah ruas jalan sehingga dapat dilakukan upaya preemptif, preventif, dan represif untuk mencegah terjadinya kecelakaan lalu lintas secara tepat guna, tepat sasaran, tepat personil, dan tepat sarana dan prasarana pendukung. Polres Probolinggo Kota sebagai salah satu polresta yang mempunyai angka kecelakaan lalu lintas yang cukup tinggi memahami begitu pentingnya analisa ilmiah terhadap kecelakaan disuatu ruas jalan, maka Polres Probolinggo Kota melakukan pendataan kecelakaan diruas jalan utama yang terdapat diwilayah hukum Polres Probolinggo Kota dan dilakukan analisa ilmiah terhadap data-data kecelakaan tersebut, serta ruas jalan yang berada didalam kota Probolinggo. Dengan didapatkannya daerah black spot (rawan kecelakaan) pada ruas jalan tersebut maka ke depan Polres Probolinggo Kota dapat melaksanakan Program Black Spot Area Therapy.

Kecelakaan merupakan suatu tuntutan yang harus dipenuhi oleh petugas, agar mendapatkan citra yang lebih baik pada masyarakat. Penanganan kecelakaan yang dilakukan oleh kepolisian merupakan sebuah pelayanan yang diberikan kepada masyarakat yang membutuhkan. Sesuai dengan tugas pokok fungsi kepolisian yaitu menjaga kemanan dan ketertiban, maka penempatan anggota polisi di pos-pos theraphy black spot, selain memantau perkembangan kasus kecelakaan lalu lintas dan faktor-faktor yang menyebabkannya, juga memiliki fungsi yang sama yaitu untuk menjaga keamanan dan ketertiban di wilayah Kota Probolinggo.

\section{Pelaksanaan penyelidikan dan penyidikan kecelakaan lalu lintas}

Polisi lalu lintas berwenang untuk melakukan penyelidikan tentang terjadinya suatu tindak pidana, yang dalam hal ini adalah kelalaian dalam mengemudikan kendaran bermotor hingga menyebabkan orang lain meninggal dunia. Penyelidikan ini dilakukan dalam rangka untuk memastikan telah terjadinya suatu tindak pidana. Dalam hal terjadi kecelakan lalu lintas, maka penyelidik polisi lalu lintas mendatangi tempat kejadian perkara (di wilayah Kota Probolinggo), dan mencari keterangan tentang kecelakan tersebut. Faktor manusia dan kendaraan masih menjadi penyebab utama kecelakaan di wilayah hukum Polres Probolinggo Kota. Hal ini tentunya menghambat kinerja polisi dalam melakukan tugas pokonya sebagai penegak hukum. Langkah-langkah yang dilakukan dalam rangka penyidikan terhadap kecelakaan yang mengakibatkan orang lain meninggal dunia adalah sebagai berikut:

\section{Melakukan olah Tempat Kejadian Perkara (TKP)}

Penyidik kepolisian dalam melakukan pembuktian terkait dengan dugaan bahwa Tersangka melakukan kealpaan dilakukan dengan melihat olah TKP. Tidak hanya olah TKP saja penyidik juga melihat apakah pengendara sudah menggunakan prinsip kehati-hatian atau belum (Julian et al 2012; Wyatt 2014). Menurut Edy Prasetyo, ukuran hati-hati ini dilihat dari jarak pengendara dengan pengendara lainnya, kecepatan yang digunakan oleh pengendara, apakah pengendara sudah mematuhi ramburambu lalu lintas atau belum serta adakah perhatian yang dilakukan oleh pengendara terhadap situasi di sekelilingnya. Dalam hal ini penyidik melakukan olah TKP untuk dapat menetukan bagaimana terjadinya kecelakaan tersebut dengan memberikan tanda ditempat ditemukannya korban dan barang bukti. Setelah pemberian tanda dilakukan pengukuran TKP dan pemasangan garis polisi. Untuk mempermudah penyidikan, penyidik membuat gambar sketsa kecelakaan dan melakukan rekayasa peristiwa.

\section{Menolong korban kecelakaan}

Saat terjadi kecelakaan lalu lintas tentu saja ada yang menjadi korban kecelakaan lalu lintas tentu saja sangat membutuhkan pertolongan satlantas Polres Pasuruan dalam hal ini terbukti memberikan 
pertolongan kepada korban kecelakaan tersebut dan memastikan korban berada ditempat yang seharusnya termasuk membawa kerumah sakit. Korban kecelakaan dan tentu saja korban kecelakaan tersebut membutuhkan pertolongan baik secara langsung maupun tidak langsung, secara langsung korban kecelakaan mungkin akan ditolong oleh warga sekitar dilokasi kecelakaan apabila kondisinya memungkinkan. Satlantas Polres Pasuruan juga memiliki fungsi untuk memberikan pertolongan bagi korban maupun pelaku yang terluka, sehingga dapat dilaksanakan langkah selanjutnya. Untuk korban kasus kecelakaan yang meningggal dunia ataupun untuk mengantarkan kerumah sakit untuk dilakukan visum atau perawatan.

\section{Melakukan penangkapan, penahanan, dan penyitaan}

Adanya fungsi melakukan penyidikan yang bagian dari upaya represif. Kepolisian juga berwenang untuk melakukan pemeriksaan atas kebenaran keterangan berkenaan dengan pemenuhan persyaratan teknis dan layak jalan kendaraan bermotor. pelaksanaan penyidikan tetap harus memberikan perlindungan terhadap penghakiman, Setelah merasa cukup dalam memberikan pertnyaan terhadap tersangka polisi melakukan pemberkasan dan melakukan penyidikan ketempat kejadian perkara dengan melakukan pemotretan, yang terdiri dari foto situasi secara keseluruhan, foto posisi dari kendaraan yang terlibat kecelakaan, foto korban sebelum dipindahkan dari TKP, foto kerusakan yang ada pada kendaraan yang terlibat kecelakaan lalu lintas dan foto bekas-bekas yang tertinggal.

Setelah terjadinya kecelakaan lalu lintas tentunya polisi harus segera melakukan penindakan kepada pelaku terjadinya kecelakaan yaitu dengan melakukan penangkapan. Hal ini bertujuan agar pelaku tidak pergi meninggalkan TKP atau berusaha melarikan diri. Penangkapan terhadap pelaku tindak pidana kelalaian yang mengakibatkan orang lain meninggal dunia adalah suatu tindakan penyidik berupa penangkapan sementara waktu kebebasan tersangka apabila telah terdapat cukup bukti, guna kepentingan penyidikan. Sesuai dengan kewajiban penyidik yang disebutkan pada Pasal 7 huruf D bahwa penyidik berwenang untuk melakukan penangkapan, penahanan, penggeledahan, dan penyitaan. Pasal 17 KUHP menyebutkan bahwa "Perintah penangkapan dilakukan terhadap seorang yang diduga keras melakukan tindak pidana berdasarkan bukti permulaan yang cukup."

\section{Kendala dalam penanganan penyidikan terhadap kecelakaan lalu lintas di Kota Probolinggo}

Dalam melakukan olah TKP, Satuan Lalu lintas Polisi Resort Probolinggo Kota hanya bisa menurunkan jumlah personil yang sedikit, karena dalam unit laka hanya memiliki personil sebanyak 11 orang termasuk di dalamnya kasatlantas kanitlaka. Tidak hanya itu sejumlah penyidik juga sangat terbatas yakni hanya berjumlah 4 orang yang terdiri dari 2 orang penyidik pembantu.

Diketahui masih kurangnya kesadaran masyarakat untuk mematuhi peraturan lalu lintas yang berakibat pada terjadinya pelanggaran lalu lintas. Hal ini diantaranya mengendarai sepeda motor dengan kecepatan tinggi, kurang merawat kendaraan, tidak menggunakan helm, parkir di area yang telah dipasangi rambu dilarang parkir, dan lain sebagainya (Hasselberg 2005; Factor 2007).

Lebih spesifik, terkait sikap, diduga pengguna jalan tidak mematuhi aturan lalu lintas dan cenderung melakukan pelanggaran karena memiliki: (1) Sikap positif terhadap pelanggaran lalu lintas, (2) Sikap negatif terhadap hukum lalu lintas, serta (3) Sikap negatif terhadap polantas. Sikap-sikap dari para pelanggar tersebut merupakan determinan dasar dari pembentukan perilaku, yaitu perilaku melanggar peraturan lalu lintas.

\section{Simpulan}

Karakteristik kecelakaan lalu lintas di Kota Probolinggo yaitu kecenderungan kecelakaan lalu lintas tersebut diawali oleh sikap pelanggar yang kemudian didukung dengan anatomi lokasi yang kurang memadai, seperti jalan sempit, kurang penempatan rambu, dan faktor manusia sebagai faktor penyebab kecelakaan. Karakteristik dari faktor manusia pada tahun 2018 adalah sebagai berikut: usia pelaku didominasi oleh usia 26-30 tahun dan 31-40, dimana pada usia tersebut, dapat dikategorikan ke 
dalam usia dewasa, dimana usia produktif sebagai pekerja. Jenis kelamin pelaku laka didominasi oleh laki-laki. Sementara profesi didominasi oleh swasta.

Faktor yang menyebabkan kecelakaan lalu lintas di Kota Probolinggo yaitu faktor kelalaian pengendara dan faktor kendaraan, dimana kelalaian pengendara terkait tidak tertib lalu lintas seperti kecepatan dan rambu lalu lintas. Sementara faktor kendaraan yang terkait dengan kendaraan jarang dipelihara oleh pengendara sehingga menyebabkan kerusakan pada kendaraan tersebut.

Penanganan penyidikan terhadap kecelakaan lalu lintas di Kota Probolinggo yaitu dengan melakukan mapping blackspot area, menolong korban kecelakaan pelaksanaan penyelidikan, penyidikan serta penangkapan/penahanan tersangka.

\section{Daftar Pustaka}

Al Qurni I (2013) Analisis Rawan Kecelakaan Lalu Lintas di Jalan Nasional Kabupaten Kendal. Jurnal Universitas Negeri Semarang.

Ambarwati L, Sulistio H, Negara GH, \& Hariadi Z (2012) Karakteristik dan peluang kecelakaan pada mobil pribadi di wilayah perkotaan. Rekayasa Sipil 4 (2):124-135.

Bjorklund GM, Aberg L (2005) Driver behaviour in intersections: Formal and informal traffic rules. Transport. Res. Part F: Traffic Psychol. Behav. 8:239-253.

Chakrabartty A \& Gupta S (2014) Traffic congestion in the metropolitan City of Kolkata. Journal of Infrastructure Development 6 (1):43-59.

Factor R, Mahalel D \& Yair G (2007) The social accident: A theoretical model and a research agenda for studying the influence of social and cultural characteristics on motor vehicle accidents. Accident Analysis \& Prevention 39 (5):914-921. doi:10.1016/j.aap.2006.12.015

Firman T (1998) The restructuring of Jakarta metropolitan area: A "global city" in Asia. Cities 15 (4):229-243.

Girotto E, de Andrade SM, González AD, Mesas AE (2016) Professional experience and traffic accidents/near-miss accidents among truck drivers. Accident Analysis \& Prevention 95:299304.

Hasselberg M, Vaez M, Laflamme L (2005) Socioeconomic aspects of the circumstances and consequences of car crashes among young adults. Social Sci. Med. 60:287-295.

Julian R, Kelty S, \& Robertson J (2012) "Get it right the first time": Critical issues at the crime scene. Current Issues in Criminal Justice 24 (1):25-37.

Kurniawan R (2016) Kinerja kepolisian dalam penanganan kecelakaan lalu lintas (Studi kasus di Polisi Resor Samarinda). E-Journal Ilmu Pemerintahan 4 (4):1879-1892.

Mesken J, Lajunen T, Summala H (2002) Interpersonal violations, speeding violations and their relation to accident involvement in Finland. Ergonomics 45 (7), 469-483.

Nainggolan A (2014) Pelaksanaan penyidikan tindak pidana kecelakaan lalu lintas yang menyebabkan matinya korban berdasarkan Undang-Undang Nomor 22 Tahun 2009 Tentang Lalu Lintas dan Angkutan Jalan. JOM Fakultas Hukum 1 (2):1-15.

Parker D, Reason JT, Manstead AS, \& Stradling SG (1995) Driving errors, driving violations and accident involvement. Ergonomics, 38 (5):1036-1048.

Rofiq M (2017) Ini Kronologi Kecelakaan di Probolinggo yang menewaskan 10 Orang. Disadur dari https://news.detik.com/berita-jawa-timur/d-3560193/ini-kronologi-kecelakaan-di-probolinggoyang-menewaskan-10-orang. Diakses 2 Mei 2018.

Sentanu AI, Djatmika P \& Navianto I (2014) Mediasi penal sebagai alternatif penyelesaian perkara kecelakaan lalu lintas yang berkorban dan tersangka memiliki hubungan keluarga (Studi di Polres Probolinggo Kota). Jurnal Hukum Fakultas Hukum Universitas Brawijaya 1-22.

Sivak M (2002) How common sense fails us on the road: contribution of bounded rationality to the annual worldwide toll of one million traffic fatalities. Transport. Res. Part F: Traffic Psychol. Behav. 5:259-269.

Steinberg F (2007) Jakarta: Environmental problems and sustainability. Habitat International 31 (34):354-365. doi:10.1016/j.habitatint.2007.06.002 
Tamin OZ (1992) Pemecahan masalah lalu linta kota besar. Jurnal PWK 4 (2). Institut Teknologi Bandung.

Tamin OZ (2005) Integrated public and road transport network system for Bandung metropolitan area (Indonesia). Proc. Eastern Asia Soc. Transport. Studies 5:1281-1300.

Undang-Undang Republik Indonesia Nomor 2 Tahun 2002 Tentang Kepolisian Negara Republik Indonesia.

Undang-Undang Nomor Tentang Kitab Undang-Undang Hukum acara Pidana, Undang-Undang Nomor 8 Tahun 1981., Lembaran Negara Republik Indonesia Nomor 76 tahun 1981.

Wyatt D (2014) Practising crime scene investigation: Trace and contamination in routine work. Policing and Society 24 (4):443-458. 